\title{
Grazing by meroplanktonic polychaete larvae may help to control nanoplankton in the NW Mediterranean littoral: in situ experimental evidence
}

\author{
D. Martin*, S. Pinedo, R. Sardá \\ Centre d'Estudis Avançats de Blanes (C.S.I.C.), Camí de Santa Bàrbara, s/n, E-17300 Blanes (Girona), Spain
}

\begin{abstract}
In this paper, we test the potential meroplankton grazing pressure on the nanoplanktonic community at the Bay of Blanes (NW Mediterranean). We used 2 abundant polychaete larvae (Prionospio malmgreni and Loimia medusa) cultured in situ in dialysis bags from which possible nanoplankton grazers other than larvae had been removed by filtration. Ingestion rates on chlorophyll a ranged from 0.001 to 0.04 and from 0.045 to $0.117 \mu \mathrm{g} \mathrm{larva}^{-1} \mathrm{~d}^{-1}$ for $P$. malmgreni and $L$. medusa, respectively. Ingestion rates on heterotrophic nanoflagellates (HNF) ranged from 2.4 to $32.3 \times 10^{3}$ and from 20.8 to $128.0 \times$ $10^{3}$ cells larva ${ }^{-1} \mathrm{~d}^{-1}$ for $P$. malmgreni and $L$. medusa, respectively. Scaling larval grazing to the natural plankton community results in: (1) a consumption on nanophytoplankton production ranging between 2.5 and $7.0 \%$, corresponding to percentages of nanophytoplankton loss in ambient waters of 2.3 to $6.4 \%$, respectively; (2) a consumption on HNF production ranging between 3.1 and $12.4 \%$, corresponding to percentages of HNF loss in ambient waters of 2.9 to $11.7 \%$, respectively. Although limited in time, the presence of planktotrophic larvae could cause an impact on nanophytoplankton populations which could be of similar relevance to that of holoplanktonic grazers, at least in shallow littoral waters of the Mediterranean Sea. Although potentially high, the estimated ingestion of nanophytoplankton by polychaete larvae was not sufficient to explain the major losses observed in the field, suggesting that these losses must be a result of consumption by other zooplanktonic grazers as well, and/or from processes other than herbivory. Contrary to nanophytoplankton and HNF, bacteria showed enhanced abundance in the presence of both polychaete larvae. Grazing by polychaete larvae caused a disruption of the grazing control exerted by HNF on bacteria. In conclusion, our results strongly indicate an important trophic role of meroplankton both as a direct control of the microbial holoplanktonic populations, and as a source of cascading effects in the microbial planktonic food webs.
\end{abstract}

KEY WORDS: Meroplankton · Polychaete larvae - Grazing - Nanoplankton control - NW Mediterranean

\section{INTRODUCTION}

The close timing between the production of pelagic larvae by benthic invertebrates and the phytoplankton blooms has been widely reported since Thorson (1946). This synchrony ensures an abundant food supply for planktotrophic larvae (Thorson 1946, Himmelman 1975), but there are 2 competing hypotheses on the

\footnotetext{
•E-mail:dani@azathoth.ceab.es
}

origin of this coupling: (1) indirect induction through the control of both the phytoplankton blooms and the gamete or larval release by physical environmental variables (Forward 1987, Giese \& Kanatani 1987), and (2) direct induction, with the increasing phytoplankton abundance acting as a chemical triggering cue for spawning (Starr et al. 1990, 1991, 1992, 1993, 1994).

Spawning of benthic invertebrates results in the release of a large number of planktotrophic larvae with a 'long planktonic life' to the pelagic system (Thorson 1950, Mileikowsky 1971, Strathmann 1987). The nour- 
ishment of these larvae will depend directly on the existing planktonic community. Planktotrophic larvae may become frequently dominant members of coastal zooplankton during the reproductive season (Thorson 1946. Anger et al. 1986. Andreu \& Duarte in press) However, the possible trophic role of these larvae in pelagic food webs remains largely unknown.

At the Bay of Blanes (NW Mediterranean) grazing by heterotrophic nanoflagellates is the main loss factor for bacteria (del Giorgio et al. in press) and picoplankton (Mura et al. 1996), whereas nanoplankton and microplankton biomass and production appear to be tightly controlled by metazoan grazers (Mura et al. 1996). In this paper, we test the potential larval grazing pressure on the nanoplanktonic community $(<20 \mu \mathrm{m})$ at the Bay of Blanes by using 2 abundant polychaete larvae (Prionospio malmgreni and Loimia medusa).

Polychaete larvae exhibit a great variety of feeding mechanisms (Strathmann 1978), most being filtrating downstream collectors. Usually, they have 2 ciliated bands, allowing the retention of particles of 2 to $20 \mu \mathrm{m}$ (Daro \& Polk 1973, Nilsen 1987, Strathmann 1987, Hansen 1991, 1993). During their reproductive period, Prionospio malmgreni and Loimia medusa are 2 abundant planktonic polychaete larvae at the Bay of Blanes. The larva of $P$. malmgreni is a typical metatrochophore of the family Spionidae, and the aulophore of $L$. medusa is a long-living pelagic larva from the family Terebellidae, each one representing 2 different larval feeding mechanisms. Larvae of P. malmgreni are fil-

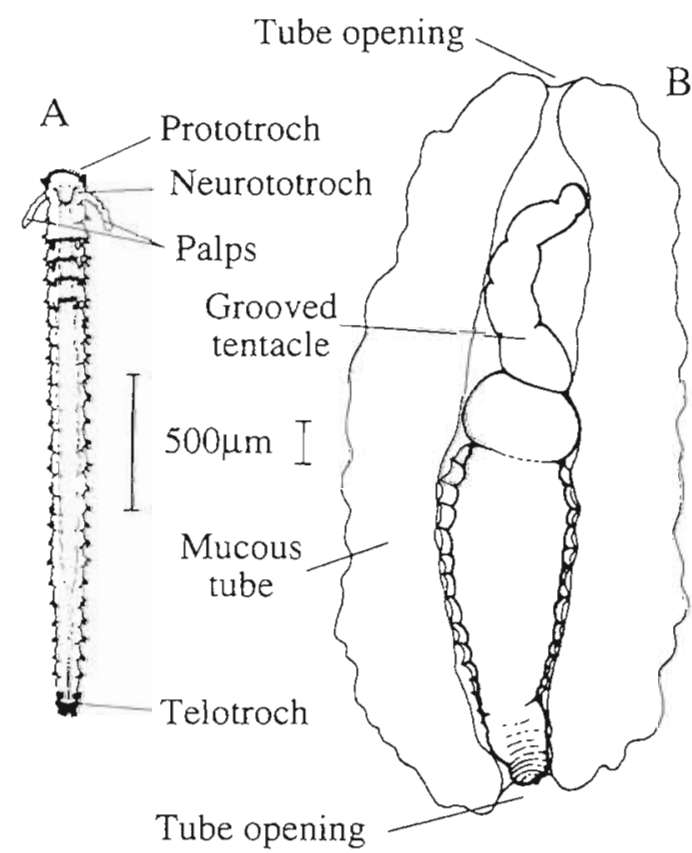

Fig. 1. External morphology of the 2 polychaete larvae used in the experiments: (A) Prionospio malmgreni, (B) Loimia medusa trating downstream collectors with long, thin bodies and 2 short palps of $1 / 10$ of the total body length (Fig. 1A). They feed through the combined effect of the permanent antero-posterior current created by the movement of the abundant short cilia of a short neurotroch, and the beating of the long cilia from the welldeveloped prototroch (D. Martin pers. obs.). The aulophores of $L$. medusa are secondary larval phases, buoyant because of the presence of mucus secretions (Nozais 1995). Food capture is based on their grooved, ciliated tentacles that, in contrast to the adult benthic phases, collect food particles from the openings of their mucous tubes (Fig. 1B). These particles are carried towards the openings of the tube by currents induced by peristaltic movements of the body (D. Martin pers. obs.).

Studies of polychaete larval feeding have been conducted in the laboratory (Blake \& Kudenov 1981, Paulay et al. 1985, Anger et al. 1986, Hansen 1993), where conditions differ from those encountered in situ (cf. Baldwin \& Newell 1991, Shimeta \& Jumars 1991). In situ manipulative experiments are, therefore, needed to assess the role of meroplanktonic polychaetes in coastal pelagic food webs

We performed larval feeding experiments, using organisms enclosed within dialysis bags suspended in situ, from which possible microplankton grazers other than larvae had been removed by filtration. Dialysis bags allow free exchange of most inorganic and organic solutes and exclude losses other than natural mortality and those attributed to the introduced polychaete larvae. Because the lower size-limit for polychaete larvae prey $(>2 \mu \mathrm{m})$ is above the size of the natural bacterioplankton community $\left(<1 \mu \mathrm{m}_{i}\right.$ Gasol et al. 1995), we considered nanophytoplankton and heterotrophic nanoflagellates as the prey items available to the polychaete larvae.

\section{MATERIAL AND METHODS}

The study was conducted in the Bay of Blanes, NW Mediterranean Sea $\left(41^{\circ} 39.90^{\prime} \mathrm{N}, 2^{\circ} 48.03^{\prime} \mathrm{E}\right)$. We used 2 of the most abundant planktonic polychaete larvae during the experimental period (Prionospio malmgreni and Loimia medusa) as test organisms. Larvae were collected using a plankton net of $150 \mu \mathrm{m}$ mesh size in the Bay of Blanes on February 8, 1995. Samples were then transferred to hermetic plastic bags, and kept in an isothermal box until sorted at the laboratory under an Olympus stereomicroscope equipped with a cold light system. Larvae were carefully pipetted and transferred to filtered seawater until the beginning of the experiment. Larvae of about 2 and $10 \mathrm{~mm}$ in length were selected for $P$. malmgreni and L. medusa, respec- 
tively. For this last species, larvae with a single tentacle were carefully selected.

To assess the response of potential prey organisms [i.e. phytoplankton, heterotrophic nanoflagellates (HNF), and bacterioplanktonl caused by the presence of larvae, we enclosed natural seawater inside dialysis bags. The dialysis bags (Spectra/Por) consisted of $500 \mathrm{ml}$ bags constructed with dialysis membranes with a molecular weight cut-off of 6000 to 8000 Da. These membranes allow diffusion of molecules smaller than proteins, which equilibrate with ambient seawater at time scales $<4 \mathrm{~h}$. The dialysis cultures were used for 3 treatments: (1) without larvae (i.e. control), (2) with 5 larvae of Prionospio malmgreni, and (3) with 2 larvae of Loimia medusa.

Seawater containing the natural subsurface holoplanktonic community was collected at the same area where larvae were captured prior to the onset of the experiments and screened through a $20 \mu \mathrm{m}$ mesh to exclude consumers other than larvae (ciliates $>100 \mu \mathrm{m}$ were also excluded). Dialysis bags were hydrated by soaking them in deionised water for $2 \mathrm{~h}$ prior to use. The bags were filled with the filtered seawater, larvae were added as appropriate, on deck of an outboard motor boat, and the bags were then closed. Small hermetic cups filled with filtered seawater were used to transport the larvae to the in situ experimental site. The dialysis bags were carefully tied to a frame, and suspended in the bay at about $1.5 \mathrm{~m}$ below the surface waves. The surface temperature during the incubation was $13.05 \pm 0.03^{\circ} \mathrm{C}$. Six dialysis bags were prepared for each treatment. Two bags per treatment were sampled at the onset of the experiment (Day 0), after $1 \mathrm{~d}$ (Day 1), and after $5 \mathrm{~d}$ (Day 5). The content of each bag was collected into a $500 \mathrm{ml}$ clean plastic container and immediately transported to the laboratory. Parallel samples of ambient seawater were also collected.

At the laboratory, all larvae inside the bags were recovered and their state of health carefully checked. Subsamples $(400 \mathrm{ml})$ were filtered through Whatman GF/F filters for fluorometric analysis of chlorophyll a (chl a) concentration (Parsons et al. 1984). The filters were homogenised in $90 \%$ acetone and refrigerated at $4^{\circ} \mathrm{C}$ for ca $6 \mathrm{~h}$. Fluorescence was measured, following extraction, in a Turner Designs fluorometer calibrated with pure chl a (Sigma Co.) (Holm-Hansen \& Riemann 1978).

Additional samples of $10 \mathrm{ml}$ (HNF) and $19 \mathrm{ml}$ (bacteria) were preserved with $2 \mathrm{ml}$ and $1 \mathrm{ml}$ of formaldehyde (5\% of final concentration), respectively. These samples were gravity-filtered at low pressure onto black Nuclepore filters (nominal pore sizes of $0.6 \mu \mathrm{m}$ for HNF and $0.2 \mu \mathrm{m}$ for bacteria), and then stained with $1 \mathrm{ml}$ of DAPI (4',6-diamidino-2-phenylindole; Marti- nussen \& Thingstad 1991) solution $\left(10 \mu \mathrm{g} \mathrm{ml}^{-1}\right)$ for 5 to 10 min. Filters were then washed twice with filtered seawater before they were mounted on a glass slide over a drop of Zeiss immersion oil, and stored frozen until microscopic examination in the laboratory. Epifluorescence microscopy, which allows unambiguous discrimination of autotrophic (i.e. containing chl a) from heterotrophic cells, was used to estimate the number of HNF $(<6 \mu \mathrm{m})$ and bacteria $(<2 \mu \mathrm{m})$. The filters were examined using a Zeiss Axioplan microscope equipped with an epifluorescence unit provided with a UV filter set (Zeiss filter 487701). Cells were counted on 100 fields (HNF) and 10 fields (bacteria) at $1000 x$ magnification (field size of $100 \mu^{2}$ ).

Ingestion rates on nanophytoplankton and HNF and bacterial loss rates were based on an exponential growth model, and were estimated from the equations provided by Frost (1972) and Saiz (1993). To estimate the percentage of total loss and the percentage of consumed production of nanophytoplankton and HNF which can be attributed to grazing by polychaete larvae in natural conditions, we used the nanophytoplankton net growth rates and loss rates in natural waters estimated by Mura et al. (1996). HNF net growth rates were estimated as the growth rates calculated from the changes in HNF abundance in ambient waters during the experimental period. Accordingly, HNF natural loss rates were calculated as the differences between gross and net growth rates. HNF production in the control bags were estimated as the maximum increase in cell numbers with time.

Differences in chl a concentration and cell numbers (bacteria and HNF) between treatments were tested by 1 -way analysis of variance (ANOVA) and Tukey HSD multiple comparisons tests. Differences in grazing and ingestion rates between treatments and days of incubation were assessed by Student's t-test. Variables were appropriately transformed whenever needed to comply with the assumptions of the parametric tests.

\section{RESULTS}

Chl a concentration on Day 0 was $1.36 \mu g \mathrm{l}^{-1}$ and showed significant changes during the experimental period in all bags (Fig. 2). However, only Loimia medusa larvae were able to cause a significant decrease in chl a concentration from Day 0 to Day 1 (Tukey test, $\mathrm{p}<0.02 \mathrm{j}$ and significant differences between all bags were found after $5 \mathrm{~d}$. In particular, only chl a concentrations in the $L$. medusa bags were significantly different from those in the control bags (Tukey test, $\mathrm{p}=$ 0.02), whereas they were not significantly different from those in the Prionospio malmgreni bags. 


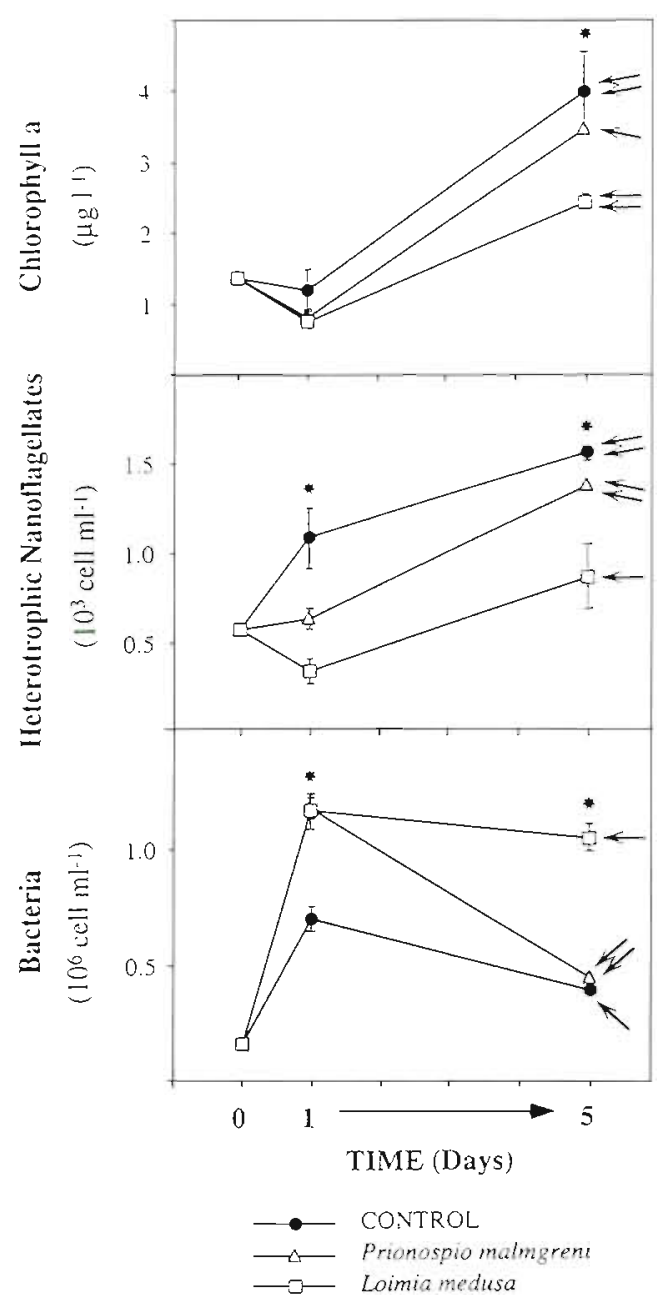

Fig. 2. Time course of the chlorophyll a concentration, HNF abundance, and bacterial abundance in control and treatment dialysis bags. Arrows indicate significant differences with time; asterisks indicate significant differences between treatments: $(\downarrow \cdot \cdot) 0.05 \geq p>0.01 ;(\|, \cdot \cdot) p \leq 0.01$

The abundance of HNF on Day 0 was 560 cells $\mathrm{ml}^{-1}$ and showed significant changes during the experimental period in all bags (Fig. 2), HNF abundance being higher on Day 5 than on Day 0 (Tukey test; control: $\mathrm{p}<0.01$; Prionospio malmgreni: $\mathrm{p}=0.01$; Loimia medusa: $\mathrm{p}<0.05$ ). However, the main increase in HNF abundance in the control bags occurred within the first day (Tukey test, $p<0.04$ ), whereas that in the treatment bags occurred between Days 1 and 5 (Tukey test; P. malmgreni: $\mathrm{p}=0.04 ;$ L. medusa: $\mathrm{p}<0.02)$. There were significant differences in HNF abundance between all bags on the 2 incubation dates. These differences were attributed to the lower HNF abundance in the $L$. medusa bags relative to the control (Tukey test; Day $1, \mathrm{p}<0.02$; Day $5, \mathrm{p}<0.03$ ) and the $P$. malmgreni (Tukey test; Day 1, $\mathrm{p}=0.05$ ) bags. HNF abundance in the $P$. malmgreni bags was always intermediate between those in the control (higher) and the L. medusa (lower) bags, being closer to that of the L. medusa bags on Day 1 and to that of the control bags at Day 5 (Fig 2).

Bacterial abundance on Day 0 was $171.6 \times 10^{3}$ cells $\mathrm{ml}^{-1}$ and showed changes during the experimental period in all bags, the trends being different depending on experimental bags (Fig. 2). Contrary to nanophytoplankton and HNF, bacterial abundance increased in the presence of both larval species, at least after $1 \mathrm{~d}$ of incubation. There were significant differences in bacterial abundance between all bags for the 2 incubation periods. On Day 1, bacterial abundance was higher in the treatment than in the control bags (Tukey test, $p<0.03$ ). Bacterial abundance in the Loimia medusa bags was significantly higher after $5 \mathrm{~d}$ than those in the control and the Prionospio malmgreni bags (Tukey test, $p<0.02$ and $p=0.04$, respectively), whereas the control and the P. malmgreni bags did not differ significantly from each other.

Nanophytoplankton ingestion by Loimia medusa was higher than that by Prionospio malmgreni on Day $1\left(0.117\right.$ and $0.04 \mu \mathrm{g}$ larva $^{-1} \mathrm{~d}^{-1}$, respectively) whereas differences were not significant on Day 5 $\left(0.045\right.$ and $0.001 \mu \mathrm{g}$ larva ${ }^{-1} \mathrm{~d}^{-1}$ for $L$. medusa and $P$. malmgreni, respectively) (Fig. 3). Accordingly, only the
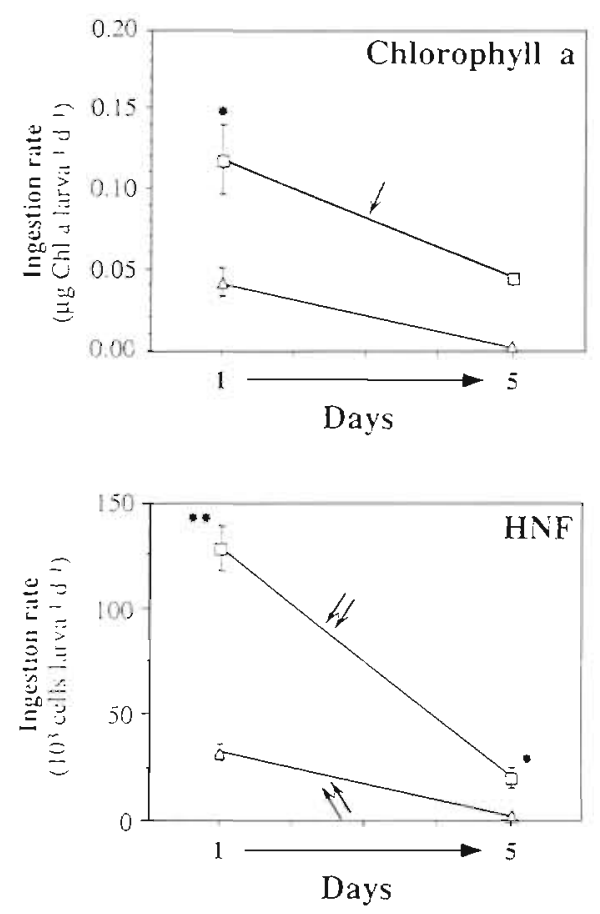

Fig. 3. Time course of the ingestion rates on chlorophyll $a$ and HNF by the larvae studied inside the dialysis bags. Arrows indicate significant differences with time; asterisks indicate significant differences between treatments: $(, \cdot \cdot) 0.05 \geq p>$ $0.01 ;(\ldots) \mathrm{p} \leq 0.01$ 
ingestion rates on nanophytoplankton by L. medusa were significantly higher on Day 1 than on Day 5.

Ingestion rates on HNF by Prionospio malmgreni were $32.3 \times 10^{3}$ cells larva ${ }^{-1} \mathrm{~d}^{-1}$ (Day 1 ) and $2.4 \times$ $10^{3}$ cells larva ${ }^{-1} \mathrm{~d}^{-1}$ (Day 5), whereas those by Loimia medusa were $128.0 \times 10^{3}$ cells larva ${ }^{-1} \mathrm{~d}^{-1}$ (Day 1 ) and $20.8 \times 10^{3}$ cells larva ${ }^{-1} \mathrm{~d}^{-1}$ (Day 5) (Fig. 3). These ingestion rates were: (1) significantly higher for L. medusa than for P. malmgreni at both incubation dates, and (2) significantly higher on Day 1 than on Day 5 for both polychaete larvae (Fig. 3)

Bacterioplankton showed negative loss rates inside the treatment bags: (1) $-0.513 \mathrm{~d}^{-1}$ (Day 1) and $-0.005 \mathrm{~d}^{-1}$ (Day 5) in the Prionospio malmgreni bags, and (2) $-0.50 d^{-1}$ (Day 1) and $-0.194 d^{-1}$ (Day 5) in the Loimia medusa bags (Fig. 4). This fact indicated enhanced bacterial growth, rather than losses, in the presence of both larvae. Bacterial loss rates were significantly lower on Day 1 than on Day 5 only in the P. malmgreni bags, whereas the differences between treatments were only significant on Day 5 (Fig. 4).

\section{DISCUSSION}

Our results demonstrate that the Loimia medusa and Prionospio malmgreni larvae have a significant impact on the dynamics of microbial planktonic communities. Both polychaete species consumed nanophytoplankton and HNF. Although the consumption rate (Fig. 3) was greater for $L$. medusa, their larvae are much larger than those of $P$. malmgreni (Fig. 1). In fact, the ingestion rate per larval body biovolume unit of the latter was higher than that of the former, both for chl $a$ and HNF (Table 1).

Bacterial growth was stimulated, not suppressed, by the presence of polychaete larvae. This indicates that the activity of the larvae triggers cascading effects on the microbial planktonic communities. Bacterioplankton populations in the Bay of Blanes are closely controlled by HNF (del Giorgio et al. in press). Hence, decimation of the HNF population by larval grazing appears to release the pressure HNFs exert on bacteria, allowing a growth increase. These effects are probably derived from the normal size-range of polychaete larval prey $(>2 \mu \mathrm{m})$, which does not include bacteria (mean size $<1 \mu \mathrm{m}$ in the Bay of Blanes; Gasol et al. 1995 ) but comprises HNFs (about $5 \mu \mathrm{m}$ ).

Whereas the results obtained unambiguously demonstrate a potential impact of the meroplanktonic polychaete larvae on microbial holoplankton communities, assessment of the importance of these mechanisms requires scaling of the experimental conditions, with larval abundance well in excess of that encountered in situ, to the natural plankton community. To

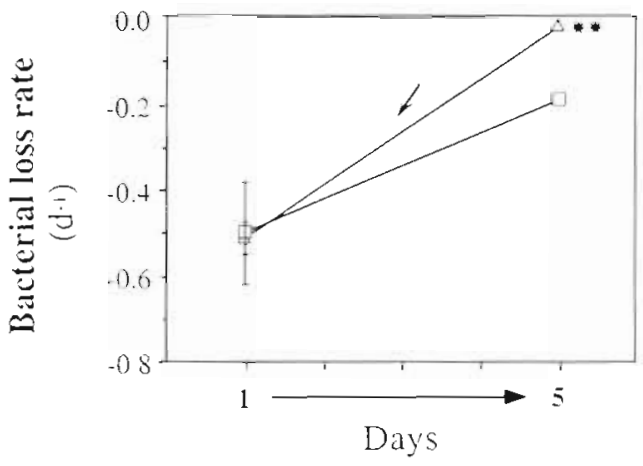

Prionospiomalmgreni $\longrightarrow$

Loimia medusa

Fig. 4. Time course of the bacterial loss rates inside the dialysis bags. Arrow indicates significant differences with time $(0.05 \geq p>0.01)$; asterisks indicate significant differences between treatments $(\mathrm{p} \leq 0.01)$

evaluate the potential grazing pressure exerted by the larvae studied on the ecosystem, we calculated the fraction of the nanophytoplankton production consumed by 500 larvae $\mathrm{m}^{-3}$ (the maximum abundance during a recruitment peak at the Bay of Blanes in February; Martin unpubl, results). We assumed a gross growth rate for nanophytoplankton of $0.61 \mathrm{~d}^{-1}$ (Mura et al. 1996) and maximum ingestion rates of $0.040 \mu \mathrm{g}$ chl a larva ${ }^{-1} \mathrm{~d}^{-1}$ (Prionospio malmgreni) and $0.117 \mu \mathrm{g}$ chl a larva-1 $\mathrm{d}^{-1}$ (Loimia medusa) (i.e. those recorded on experimental Day 1). Based on the chl a concentration at the beginning of our experiment, these assumptions result in a daily production of about $1.14 \mathrm{mg}$ chl a $\mathrm{m}^{-3}$ of which 2.54 and $7.00 \%$ would be consumed by P. malmgreni and L. medusa, respectively. Assuming a nanophytoplankton loss rate of $0.65 \mathrm{~d}^{-1}$ (Mura et al. 1996), consumption by these larvae would account for 2.33 and $6.43 \%$ of the losses, respectively.

Potential ingestion rates on the HNF population existing in ambient waters at the Bay of Blanes by larval grazing during the experimental period were extrapolated assuming the same scenario of polychaete larval abundance considered above (i.e.

Table 1. Larval ingestion rates of chlorophyll a (chl a) and heterotrophic nanoflagellates (HNF) per larval body biovolume unit (LBB). DI: days of incubation

\begin{tabular}{|c|c|c|c|c|}
\hline Species & $\begin{array}{c}\mathrm{LBB} \\
\left(\mathrm{mm}^{3}\right)\end{array}$ & DI & $\begin{array}{c}\text { Chl a } \\
\left(\mu g \mathrm{~d}^{-1} \mathrm{~mm}^{-3}\right)\end{array}$ & $\begin{array}{c}\text { HNF } \\
\left.\text { (cells } \mathrm{d}^{-1} \mathrm{~mm}^{-3}\right)\end{array}$ \\
\hline $\begin{array}{l}\text { Prionospio } \\
\text { malmgreni }\end{array}$ & 0.014 & $\begin{array}{l}1 \\
5\end{array}$ & $\begin{array}{l}2.87 \\
0.09\end{array}$ & $\begin{array}{l}2.31 \times 10^{6} \\
0.17 \times 10^{6}\end{array}$ \\
\hline $\begin{array}{l}\text { Loimia } \\
\text { medusa }\end{array}$ & 78.7 & $\begin{array}{l}1 \\
5\end{array}$ & $\begin{array}{l}1.48 \times 10^{-3} \\
0.57 \times 10^{-3}\end{array}$ & $\begin{array}{l}1.63 \times 10^{3} \\
0.26 \times 10^{3}\end{array}$ \\
\hline
\end{tabular}


500 larvae $\mathrm{m}^{-3}$ ). We considered a scenario characterised by $560 \mathrm{HNF}^{-1}$ (i.e. the abundance in ambient waters at the beginning of the experiment), and a gross HNF growth rate of $0.65 \mathrm{~d}^{-1}$ (i.e. the rate observed in control bags after $1 \mathrm{~d}$ of incubation). Assuming maximum ingestion rates on HNF of $32.3 \times 10^{3}$ cells larva $^{-1}$ $\mathrm{d}^{-1}$ (Prionospio malmgreni) and $128.0 \times 10^{3}$ cells larva ${ }^{-1}$ $\mathrm{d}^{-1}$ (Loimia medusa) (i.e. those recorded on experimental Day 1), the consumption expected by larval grazing on HNF would range between $3.14 \%$ ( $P$. malmgreni) and $12.44 \%$ (L. medusa). The percentage of HNF losses in ambient waters attributable to these larval populations would range between 2.95 and $11.69 \%$, respectively. Polychaete larvae appeared to be able to consume a higher percentage of the HNF production than what was calculated as loss of the daily nanophytoplankton production. Moreover, the percentage of HNF consumed was of similar magnitude as the percentages of HNF loss in ambient waters. Since grazing by polychaete larvae appeared to be effective to control the growth of HNF inside the dialysis bags, we suggest that larvae alone may keep the same potential control on HNF in ambient waters.

It has been suggested that metazoan grazers play a major role in controlling the nanophytoplankton production and biomass in the Bay of Blanes (Mura et al 1996). This control has usually been attributed to holoplanktonic metazoans (mainly crustaceans) due to their relatively high abundance when compared to that of meroplankton. In the NW Mediterranean littoral waters, the most important phytoplankton bloom occurs in late winter (Mura et al. in press), and is followed by the main reproductive period of macrobenthic species in spring (Pinedo et al. in press). Thus, meroplanktonic larvae appear in the water column in early spring (Andreu \& Duarte in press), resulting in the dominance of the zooplankton community in the Bay of Blanes by meroplankton. Meroplankton can contribute up to $60 \%$ of the community biomass, while the abundance of other planktonic consumers (e.g. copepods) is an order of magnitude higher than that of larvae (Andreu \& Duarte in press)

Assuming a maximum ingestion rate of $0.045 \mu \mathrm{g} \mathrm{chl} \mathrm{a}$ $\mathrm{d}^{-1}$ for individual copepods ( $E$. Saiz pers comm.), the percentage of nanophytoplankton production considered in the above scenario consumed by a copepod population of 2000 ind. $\mathrm{m}^{-3}$ (the abundance in February at the Bay of Blanes; Martin unpubl. obs.) would be $7.88 \%$, whereas the percentage of loss attributable to this copepod population would be $7.23 \%$. The values estimated for polychaete larvae are, thus, slightly below those that can be attributed to copepods. However, they are within the same order of magnitude. Therefore, our results suggest that, although potentially high, the estimated ingestion of chlorophyll a by polychaete larvae and/or copepods was not sufficient to explain the major loss of nanophytoplankton observed in situ.

Bacterioplankton and HNF populations can be controlled either by resource availability (bottom up control) or by predation pressure (top down control). It has been suggested that ambient nutrient and dissolved organic carbon (DOC) concentrations and temperature set an upper limit to bacterial maximum growth rates, whereas grazing by flagellate protists determines the net growth rates and the final number of bacteria, even at the low ambient nutrient and organic carbon concentrations present in the Bay of Blanes (del Giorgio et al. in press). In fact, when bacteria are top down controlled by HNF, HNF are bottom up controlled (Gasol 1994). The situation found in the natural planktonic community at the beginning of our experiment corresponded to a top down control of bacterial populations, with low bacterial abundance (i.e. $171.6 \times 10^{3}$ cell $\mathrm{ml}^{-1}$ ) and high HNF abundance (i.e. 560 cells $\mathrm{ml}^{-1}$ ). These relative densities suggest the HNF to be at the maximum attainable abundance proposed by Gasol (1994) (Fig. 5), the HNF grazing pressure on bacteria being, thus, closer to the maximum sustainable predation limit.

During the course of our experiment, bacterial density inside the control bags increased relatively more than that of their predators (the HNF), resulting in a release of the situation of top down control after $1 \mathrm{~d}$ (Fig. 5). Five days later, both HNF and bacteria populations had densities which were about 2.7 and 2.3 times higher than those at the onset of the experiment. However, the equilibrium returned to a situation where grazing by HNF could control bacterial density again (Fig. 5). Our experimental design allowed us to assume an absence of HNF predators in the control bags (polychaete larvae also absent). Therefore, the HNF were able to recover their grazing control on the bacterial population in the absence of predators of protozoans, as already demonstrated in experimental enclosures (e.g. Andersen \& Fenchel 1985, Bloem \& Bär-Gilissen 1989)

The presence of effective HNF predators disturbed the sequence observed in the control bags. Both polychaete larvae caused a disruption of the control exerted by HNF at Day 1 (Fig. 5). Two combined mechanisms may contribute to this effect: (1) an increase of bacterial growth related to the accumulation of larval faecal dissolved organic matter (DOM) and pellets, which are retained inside the dialysis membrane, and (2) a depression of the net growth of the HNF populations due to larval grazing pressure, thereby reducing HNF grazing pressure on bacteria. HNF abundance was about 1.7 and 3.3 times higher inside the control bags than inside the Prionospio malmgreni and Loimia medusa bags, respectively, supporting the plausibility of the second mechanism postulated. 


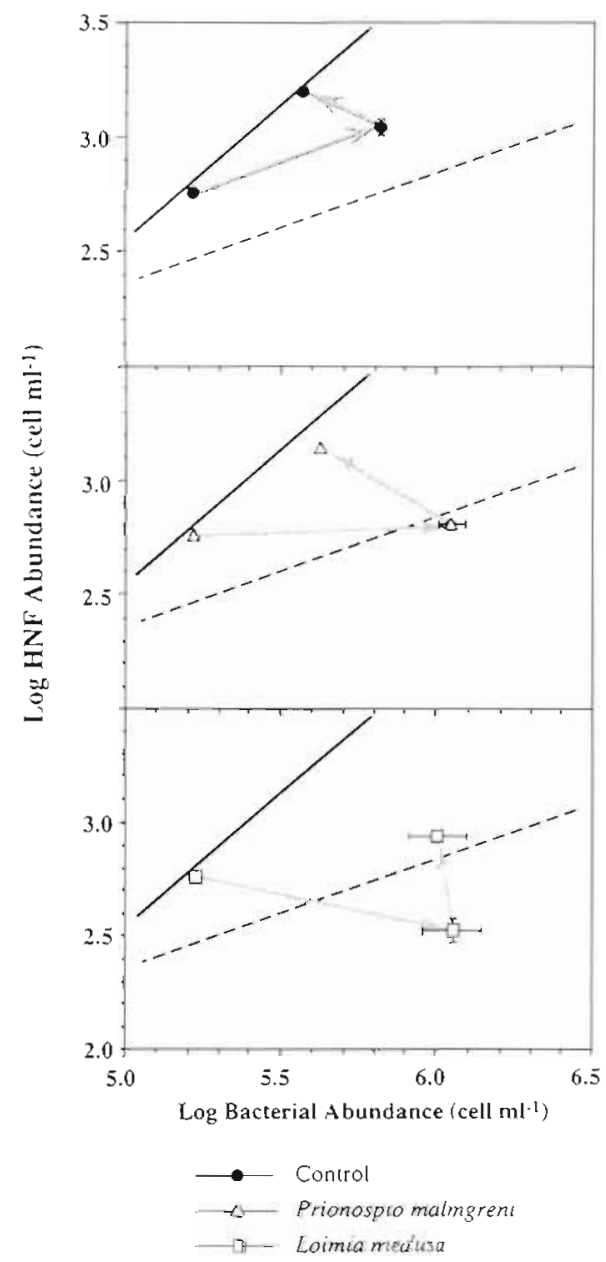

Fig. 5. Time course of the relationships between bacteria and HNF abundance (as log cells $\mathrm{ml}^{-1}$ ) in control and treatment dialysis bags. Black line: maximum attainable abundance limit; dotted line: mean realised abundance line, as the border between top down (downwards) and bottom up (upwards) situations of control of the HNF population (from Gasol 1994). Arrows indicate the direction of change during the course of the experiment.

As a consequence of the exponential HNF growth model, the relative loss of the HNF populations caused by larval feeding (represented by the ingestion rates in Fig. 3) were lower after $5 \mathrm{~d}$ of incubation. Protists were thus able to recover their control on the bacterial growth. However, inside the bags, the influence of the larvae of the 2 polychaete species on the HNF populations differed. The Prionospio malmgreni treatments showed an equilibrium between HNF and bacterial densities nearly identical to those in the control bags (Fig. 5). This suggests that these larvae were actively feeding during the course of the experiment, but were finally unable to maintain their control on the HNF population. Conversely, the potential control of HNFs derived from the feeding activity of Loimia medusa lar- vae was maintained after $5 \mathrm{~d}$ of incubation, these larvae still being able to significantly reduce the grazing pressure of HNF on bacteria by the end of the experiment (Fig. 5). As a consequence, the ratio between bacteria and HNF densities inside the bags containing these larvae was significantly different from that inside the control bags (Fig. 5).

The existence of pelagic, planktotrophic stages in the life cycle of benthic organisms has been explained as a migration into a different trophic compartment to successfully metamorphose without taxing the adult energy budget, with dispersal as a consequence (Strathmann 1985, Giangrande et al. 1994). However, the transfer to a different compartment also involves that larvae become necessarily integrated in new trophic pathways. Although limited in time (i.e. from less than $1 \mathrm{~d}$ to a little more than $1 \mathrm{mo}$ ), their presence could cause an impact which could be of similar relevance to that of holoplanktonic grazers, at least in shallow littoral waters of the Mediterranean Sea. In conclusion, our results strongly indicate an important trophic role for meroplanktonic larvae both as a direct control of microbial holoplanktonic populations, and as a source of cascading effects in the microbial planktonic food webs. Therefore, the trophic role of meroplankton as an integrated component of the pelagic system cannot be neglected any longer.

Acknowledgements. We are indebted to C. M. Duarte for insightful comments on the manuscript and J. M. Gasol for discussion on the 'cascading effect'. M. P. Mura and S. Agusti helped with field work and chlorophyll a measurements, respectively. The microbiology team of the Institute of Marine Sciences of Barcelona helped with initial treatment of microbial samples. M. P. Mura and B. Vidondo patiently clarified our doubts on microbial cell counting. We thank $T$ Granata for carefully checking the last version. This is a contribution to the project AMB94-0746 funded by the C.I.C.Y.T of Spain. D.M. and S.P. were supported by a research contract of the C.S.I.C of Spain and a predoctoral fellowship from the M.E.C. of Spain, respectively.

\section{LITERATURE CITED}

Andersen P, Fenchel F (1985) Bacterivory by microheterotrophic flagellates in seawater samples. Limnol Oceanogr 30:198-202

Andreu P, Duarte CM (in press) Zooplankton seasonality in Blanes Bay (NW Mediterranean). In: Duarte CM (ed) Seasonality in Blanes Bay: a paradigm of the NW Mediterranean littoral. Publ Espec Inst Esp Oceanogr 22

Anger K, Anger V, Hagmeier E (1986) Laboratory studies on larval growth of Polydora ligni, Polydora ciliata, and Pygospio elegans (Polychaeta, Spionidae). Helgoländer Wiss Meeresunters 40:377-395

Baldwin BS, Newell RIE (1991) Omnivorous feeding by planktotrophic larvae of the eastern oyster Crassostrea virginica. Mar Ecol Prog Ser 78:285-301

Blake JA, Kudenov JD (1981) Larval development, larval nutrition and growth for two Boccardia species (Poly- 
chaeta: Spionidaef from Victoria, Australia. Mar Ecol Prog Ser 6:175-182

Bloem J, Bär-Gilissen MJB (1989) Bacterial activity and protozoan grazing potential in a stratıfied lake. Limnol Oceanogr 34:297-309

Daro MH, Polk P (1973) The autoecology of Polydora ciliata along the Belgian coast. Neth J Sea Res 6:130-140

del Giorgio PA, Gasol JM, Vaqué D, Mura MP, Agustí S, Duarte CM (in press) Protistan-control of the production of metabolically active cells in coastal marine bacterioplankton. Limnol Oceanogr

Forward RB Jr (1987) Larval release rhythms of decapod crustaceans: an overview. Bull Mar Sci 41:165-176

Frost BW (1972) Effects of size and concentration of food particles on the feeding behavior of the marine planktonic copepod Calanus pacificus. Limnol Oceanogr 17: $805-815$

Gasol JM (1994) A framework for the assessment of top-down vs bottom-up control of heterotrophic nanoflagellate abundance. Mar Ecol Prog Ser 113:291-300

Gasol JM, del Giorgio PA, Massana R, Duarte CM (1995) Active vs inactive bacteria: size-dependence in a coastal marine plankton community. Mar Ecol Prog Ser 128:91-97

Giangrande A, Geraci S, Belmonte G (1994) Life-cycle and life-history diversity in marine invertebrates and the implications in community dynamics. Oceanogr Mar Biol Ann Rev 32:305-333

Giese AC, Kanatani H (1987) Maturation and spawning. In: Giese AC, Pearse JS, Pearse VC (eds) Reproduction of marine invertebrates, Vol IX, General aspects: seeking unity in diversity. Blackwell Scientific Publications, Palo Alto, CA, p 251-329

Hansen B (1991) Feeding behaviour in larvae of the opisthobranch Philine aperta. II. Food size spectra and particle selectivity in relation to larval behaviour and morphology of the velar structure. Mar Biol 111:263-270

Hansen B (1993) Aspects of feeding, growth and stage of development by trochophora larvae of the boreal polychaete Mediomastus fragile (Rasmussen) (Capitellidae). J Exp Mar Biol Ecol 166:273-288

Himmelman JH (1975) Phytoplankton as stimulus for spawning in three marine invertebrates. J Exp Mar Biol Ecol 20 $199-214$

Holm-Hansen O, Riemann B (1978) Chlorophyll a determination improvements in methodology. Oikos 30:438-447

Martinussen I, Thingstad TF (1991) A simple double staining technique for simultaneous quantification of auto- and heterotrophic nano- and picoplankton. Mar Microb Food Webs 5:5-11

Mileikowsky SA (1971) Types of larval development in marine bottom invertebrates, their distribution and ecological significance: a re-evaluation. Mar Biol. 10:193-213

Mura MP. Agustí S. Cebrián J. Satta MP (in press) Seasonal variability of phytoplankton biomass and community composition in Blanes Bay (1992-1994). In: Duarte CM (ed) Seasonality in Blanes Bay: a paradigm of the NW Mediterranean littoral. Publ Espec Inst Esp Oceanogr 22

Mura MP, Agustí $S$, del Giorgio PA, Gasol JM, Vaqué D, Duarte CM (1996) Loss-controlled phytoplankton production in nutrient-poor littoral waters of the NW Mediterranean: in situ experimental evidence. Mar Ecol Prog Ser $130: 213-219$

This article was submitted to the editor
Nilsen C (1987) Structure and function of metazoan ciliate bands and their phylogenetical significance. Acta Zool 68: $205-262$

Nozais C (1995) Impact des processus biologiques et des paramètres physiques sur la présence planctonique des larves d'invertébrés benthıques et sur leur recrutement en baie de Banyuls. Doctoral thesis, Université de Paris VI, Banyuls sur Mer

Parsons TR, Maita Y, Lalli CM (1984) A manual of chemical and biological methods for seawater analysis. Pergamon Press, Oxford

Paulay G, Boring L, Strathmann RR (1985) Food limited growth and development of larvae: experiments with natural sea water. J Exp Mar Biol Ecol 93:1-10

Pinedo S, Sardá R, Martin D (in press) Seasonal dynamics and structure of soft-bottom assemblages in Blanes Bay (NW Mediterranean Sea). In: Duarte CM (ed) Seasonality in Blanes Bay: a paradigm of the NW Mediterranean littoral. Publ Espec Inst Esp Oceanogr 22

Saiz E (1993) Sources of variability in zooplankton feeding experiments: the importance of accurate determination of algal growth rates. Scient Mar 57:23-29

Shimeta J, Jumars PA (1991) Physical mechanisms and rates of particle capture by suspension-feeders. Oceanogr Mar Biol Ann Rev 29:191-257

Starr M, Himmelman JH, Therriault JC (1990) Direct coupling of marine invertebrate spawning with phytoplankton blooms. Science 247:1071-1074

Starr M. Himmelman JH, Therriault JC (1991) Coupling of nauplii release in barnacles with phytoplankton blooms: a parallel strategy to that of spawning in the sea urchin Strongylocentrotus droebachiensis. J Plankton Res 13: 561. -571

Starr M, Himmelman JH, Therriault JC (1992) Isolation and properties of a substance from the diatom Phaeodactilum tricornutum which induces spawning in the sea urchin Strongylocentrotus droebachiensis. Mar Ecol Prog Ser 79: $275-278$

Starr M, Himmelman JH, Therriault JC (1993) Environmental control of green sea urchin, Strongylocentrotus droebachiensis, spawning in the St Lawrence Estuary. Can J Fish Aquat Sci 50:894-901

Starr M, Therriault JC, Conan GY, Comeau M, Robichaud G (1994) Larval release in a sub-euphotic zone invertebrate triggered by sinking phytoplankton particles. J Plankton Res 16:1137

Strathmann RR (1978) The evolution and loss of feeding larval stages of marine invertebrates. Evolution 32:894-906

Strathmann RR (1985) Feeding and non-feeding larval development and life-history evolution in marine invertebrates. Ann Rev Ecol Syst 16:339-361

Strathmann RR (1987) Larval feeding. In: Giese AC, Pearse JS, Pearse VC (eds) Reproduction of marine invertebrates, Vol IX, General aspects: seeking unity in diversity. Blackwell Scientific Publications, Palo Alto, CA p $465-550$

Thorson G (1946) Reproductive and larval development of Danish marine bottom invertebrates, with special reference to planktonic larvae in the Sound (Øresund). Medd Dan Fisk Havunders 4:1-523

Thorson G (1950) Reproductive and larval ecology of manne bottom invertebrates. Biol Rev 25:1-45

Manuscript first received: March 22, 1996

Revised version accepted: September 12, 1996 